\title{
Ny studie om skiftarbeid og helseplager
}

Ifølge rapporter fra Statens arbeidsmiljøinstitutt kan skiftarbeid forstyrre døgnrytme, søvn og gi økt ulykkesrisiko. Forskere skal nå overvåke søvnen til 600 sykepleiere som jobber turnus.

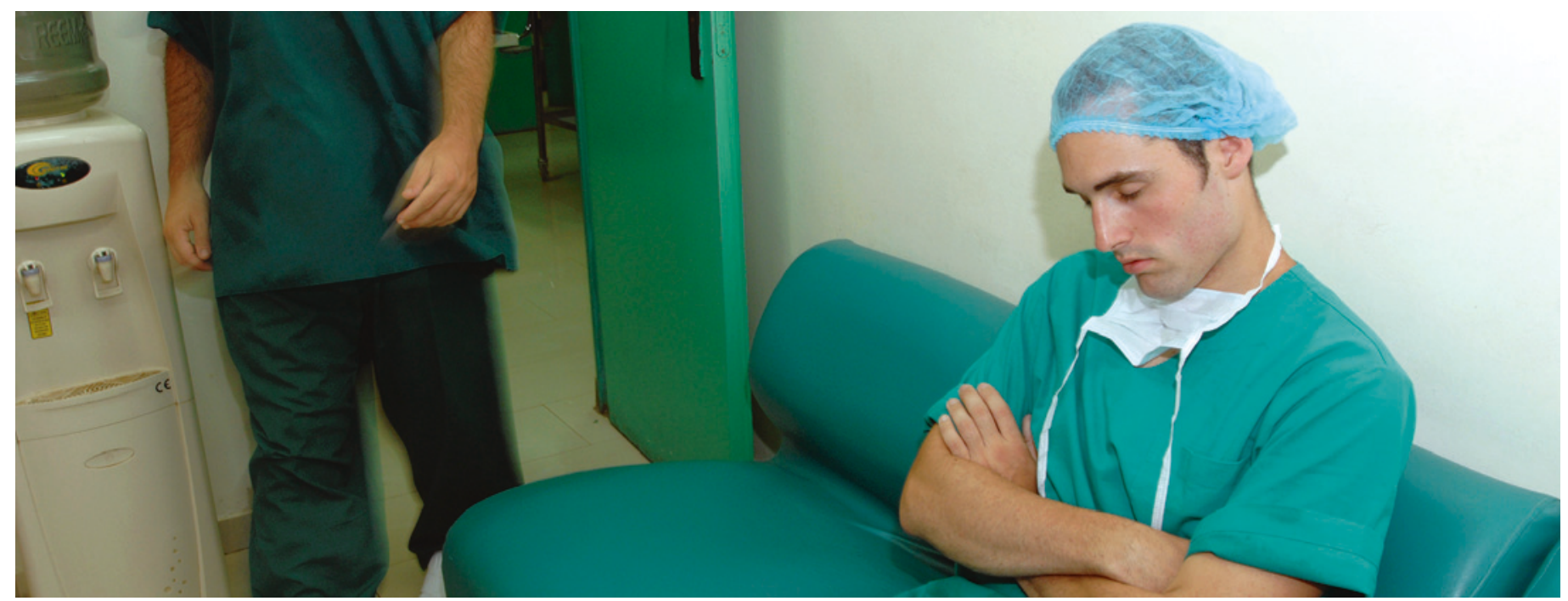

Illustrasjonsfoto: Stewart Goldstein/Medicimage/NTBscanpix

Det er forsker og lege Kristian Bernhard Nilsen ved Oslo universitetssykehus som står bak prosjektet sammen med forsker Dagfinn Matre ved Statens arbeidsmiljøinstitutt (STAMI) (1).

\section{Må stå lenger i arbeid}

Bakgrunnen for prosjektet er den store andelen skiftarbeidere innen helsevesenet.

- Et økende antall eldre vil kreve flere hender, og det er vesentlig at ansatte kan stå lenge $i$ arbeid. Det er derfor viktig for den enkelte at turnusen legges opp på en måte som ikke skaper plager, sier Matre til Tidsskriftet.

I motsetning til store spørreundersøkelser der man kartlegger sykdom og helseutfall flere år etter at man startet i et yrke, har denne studien en kortere tidshorisont og tett oppfølging, sier Matre.

Datainnsamlingen startet i midten av september og vil foregå frem til sommeren 2015.

\section{Daglig rapportering}

I fire uker rapporterte de 600 deltakerne daglig om arbeidstid, søvn og helseplager via smarttelefon. Forskerne sitter dermed igjen med detaljerte data på hvilken tid av døgnet de gjorde hva, hvor lenge de jobbet, når de la seg, hvor lenge de sov, hvor mange ganger de våknet osv.

- I tillegg til rapportering via smarttelefon har vi en del spørsmål om helseplager som hodepine, ryggvondt og infeksjoner. Slik kan vi kartlegge om det er noen sammenheng mellom arbeidstid og subjektive helseplager, sier Matre.

\section{$\emptyset k t$ risiko for feilbehandling}

I en rapport om arbeidstid og helse fra 2008 konkluderte Statens arbeidsmiljøinstitutt blant annet med at lange arbeidsøkter og skiftarbeid, særlig nattarbeid, kan føre til nedsatt funksjon med påfølgende økt risiko for å begå feil (2). Instituttet har i 2014 oppdatert kunnskapsstatusen ved å gjennomgå relevante artikler som er publisert i perioden siden forrige rapport og frem til 2012 (3). Den nye rapporten har ingen nye konklusjoner. Artikler var imidlertid med på å styrke noen av holdepunktene: Både lang arbeidstid, nattarbeid og roterende skift påvirker sikkerhet og gir økt risiko for skader/ulykker i arbeidslivet, skriver instituttet på sine nettsider (3).

Les hele saken på www.legejobber.no

\section{Elisabeth Jacobsen}

Tidsskriftet

\section{Litteratur}

1. Forskning.no. Skal finne ut om sykepleiere får dårlig helse av skiftarbeid. http://forskning.no/ helse-forebyggende-helse-sovn-arbeid/2014/09/ skal-finne-ut-om-sykepleiere-far-darlig-helse-av (8.1.2015).

2. Statens arbeidsmiljøinstitutt. Arbeidstid og helse - en systematisk litteraturstudie. STAMI-rapport nr. 21/2008. www.stami.no/arbeidstid-og-helse (8.1.2015).

3. Statens arbeidsmiljøinstitutt. Arbeidstid og helse - oppdatering av en systematisk litteraturstudie. STAMI-rapport nr. 1/2014. www.stami.no/stamirapport-arbeidstid-og-helse-en-systematisklitteraturstudie (8.1.2015).
«Et økende antall eldre vil kreve flere hender, og det er vesentlig at ansatte kan stå lenge i arbeid»

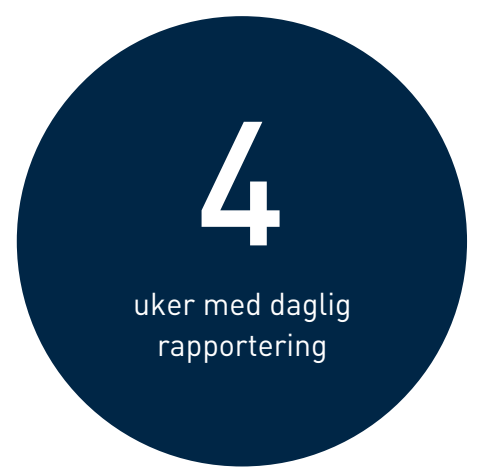

